\title{
NURSES' CARING BEHAVIORS IN THE IMPLEMENTATION OF PERIOPERATIVE NURSING CARE IN PUBLIC HOSPITALS OF BAHTERAMAS KENDARI
}

\author{
(Perilaku Caring Perawat dalam Pelaksanaan Asuhan Keperawatan Perioperatif di \\ BLUD RSU Bahteramas Kendari)
}

\author{
Heltty \\ Health Science Collage of Mandala Waluya Kendari Southeast Sulawesi \\ Jend. A.H. Nasution G.37 Kambu Telp. Number: (0401) 393176 \\ E-mail: dindakeisha01@gmail.com
}

\begin{abstract}
ABSTRAK
Pendahuluan. Caring merupakan fokus utama dalam bidang keperawatan. Caring berhubungan dengan kualitas asuhan keperawatan. Tuntutan masyarakat terhadap kualitas asuhan keperawatan semakin meningkat. Tujuan penelitian ini adalah menganalisis perilaku caring perawat dalam pelaksanaan asuhan keperawatan perioperatif di BLUD RSU Bahteramas Kendari. Metode. Penelitian ini adalah penelitian kualitatif: naturalistik. Metode pemilihan partisipan yang digunakan adalah purposive sampling sebanyak 6 partisipan (perawat). Data didapatkan melalui observasi dengan menggunakan panduan observasi berupa instrument asessment perilaku caring perawat yaitu Thai Nurses' Caring Behaviour (TNCB). Analisis data kualitatif dilakukan secara interaktif dan berlangsung secara terus-menerus sampai tuntas, sehingga datanya sudah jenuh. Hasil. Hasil penelitian mendeskripsikan partisipan telah menunjukkan perilaku caring dengan cukup baik, meskipun tidak semua aspek dalam perilaku caring perawat dapat dilakukan. Diskusi. Peningkatan pengetahuan dan keterampilan perawat perlu terus dilakukan sebagai upaya mengembangkan caring dalam praktik pelayanan keperawatan termasuk dalam pemberian asuhan keperawatan perioperatif.
\end{abstract}

Kata kunci: Caring, Perawat, Asuhan keperawatan perioperatif

\begin{abstract}
Introduction. Caring is the main focus in the field of nursing. Caring relate to the quality of nursing care. Public demand to the quality of nursing care is increasing. The purpose of this study was to analyze the nurses' caring behavior in the implementation of perioperative nursing care in public hospitals of Bahteramas Kendari. Methode. This research was qualitative research: naturalistic. Participant selection method used was purposive sampling as many as six participants (nurses). The data obtained through observation using the observation guide in the form of a nurse caring behavior assessment instrument that Thai Nurses' Caring Behavior (TNCB). Qualitative data analysis was done interactively and lasted continuously until complete, so that the data was saturated. Result. Results of the study showed that participants described caring behavior quite well, although not all aspects of the nurse caring behaviors can be done. Discussion. Increasing in knowledge and skills nurses need to be done in an effort to develop caring in the practice of nursing services included in perioperative nursing care.
\end{abstract}

Keywords: Caring, Nurse, Perioperative Nursing Care

\section{INTRODUCTION}

Caring is the main focus in the field of nursing. The concept of nursing caring have been began since Florence Nightingale (1860) and developed by several experts in nursing as Watson (1979), Leininger (1984), and Swanson (1999). Caring is the essence of nursing that differentiate with other professions, dominate, unites and animates the nursing actions (Nursalam, 2014).

Caring becomes the foundation or foundation on building the relationship (Hill,
2013). It is believed that every human being needs help, and that is the fixed aspect of caring values. Caring relate to the quality of nursing care. Public demand to the quality of nursing care is increasing. Merkouris et al. (2013) found that the demands to patients satisfaction is increasing.

Samina et al., (2008) states that patients with a surgical diagnosis have a better perception of nursing care so that the demand on nursing care is higher. Meanwhile, Mira et al., (2009) reported that surgical patients' satisfaction is influenced by the nurse's ability 
to provide information related to discharge, agility to respond, and the ability to understand the needs of the patient.

These capabilities are reflected in the implementation of nursing care. Surgical cases increased more years, so that the necessary expertise and leading edge skills in management. Surgical nurses are required to provide perioperative nursing care that begins during the preparation of the operation until the end of the operation holistically based on knowledge and nursing skills including therapeutic communication.

Perioperative periods cause physical and psychological stressors for patients and their families (Kostak, 2007). Prevention of physical and psychological stressors patients becomes important during the perioperative period. This can be prevented by supporting the needs of surgical patients and family members, who are also part of perioperative nursing care. Through caring behavior, a surgical nurse can help surgical patients to more easily cope with the trauma of surgery, reduce post-operative pain, prevent post operative complications, reduce the time, cost of treatment and cure (Mira, et al., 2009).

Werner et al. (2012) reported that emotional well-being, emotional comfort, coverage, security, hope, and patient satisfaction with the hospital, the nurse-patient relationship and healing are affected positively by nurses caring behavior.

In Public Hospital of Bahteramas Kendari, Southeast Sulawesi shows that every year following surgery is increase. The results of observations the authors found that during the perioperative nursing care, there are nurses who are less listened to the complaints of patients, rarely communicate with patients, lack of attention to the patient, the lack of preoperative administration of health education for patients, lack of action observation and monitoring, nurses are rarely seen in beside to the patient for sharing.

\section{METHODS}

The type of research in this study was qualitative research: naturalistic with a thorough observation on the behavior of the nurses for conducting activities in hospitals, especially in providing perioperative nursing care. This research was conducted at Public Hospital of Bahteramas Kendari Southeast Sulawesi starting July $1^{\text {st }}$ to August $1^{\text {st }} 2014$. Observations made in the Surgical Ward and the operating room (especially in space recovery room (RR).

Participants in this study were nurses in public hospitals of Bahteramas who treat surgical patients amounted to 6 people with educational background are ners, Bachelor of Nursing and Associate Expert (Diploma). Participant selection method used was purposive sampling with inclusion criteria.

Researchers using participant observation guide in the form of a nurse caring behavior assessment instrument developed by Suphaphon Udomluck et al (2010) is a Thai Nurses' Caring Behavior (TNCB). The researchers chose this instrument as a guide for observation instrument based on the study of literature that is based on the fusion of Caring theory developed by Watson and Swanson, as well as the similarities of Indonesian culture that is Asian cultures because the theory is developed in Thailand.

Data collection methods used were observation that passive participation of researchers came in the room surgical treatments, Operating room and recovery room. Researchers observed nurse caring behavior while they ware providing nursing care, but researchers are not involved in these activities. The observations were made with the aid of a checklist observation guide and logbook. The data is taken directly from the natural setting. The data collected were retested and then match results to the participants.

Test the validity of the data in this study included a test of credibility (trust), transferability, dependability, and comfirmability. The data and interpretation of the data is done on an ongoing basis and communicated to participant.

Data analysis in qualitative research carried out at the time of data collection in progress and after completion of data collection in a given period. Miles and Huberman (1984, 
in Sugiono, 2011) that the activity in qualitative data analysis is done interactively and lasted continuously until complete, so that the data is saturated. Activity in the analysis of data, namely data reduction (data reduction), the data display (presentation of data), and conclusion drawing (verification).

\section{RESULTS}

Based on the results of data analysis, the researcher found six clusters of research themes that explain the problem. The cluster themes are behaviors that include nurses caring aspects, there were utilizing knowledge and skills, effective communication, support, respect, being with and doing for. The results of the observations of this study are as follow:

\section{Utilizing knowledge and skills}

The results observation obtained that not all participants know about caring, there are four participants revealed that caring is limited as a concern for the patient. Not to understand that the concern is for the patient to use as a foundation of knowledge in attitude and action towards patients. In practice seem all participants respect the values of the patient, especially when providing nursing care. However results of observation also showed that in providing nursing care, less participants adhere to the established standards, such as when the preoperative, participants provide less health education related to the operation to be performed and what are the things that should be done when the postoperative patient. The health education carried out is not given in a structured and no evaluation of the patient and families understanding of health education materials are provided.

In the preoperative management of overcoming anxiety is still less given. Management of anxiety is limited to a brief communication of participants who convince the patient that the surgery will go well. Information about the operation to be undertaken given the patient is still lacking. Researchers observed participants rarely discussed with the patient and patient's family. Looks participants rarely meet patients.
Similarly, the management of postoperative pain, patients is less explained about how to cope with pain during postoperative. It appears that the explanation of the management of postoperative pain more given moment is not when the postoperative and preoperative treatment of participants more frequently used drug administration as recommended (advice) physicians in pain management compared with the actions of other nurses independently as pain distraction techniques (relaxation deep breath, music therapy, etc.). In the postoperative period, participants rarely even being motivate patients to perform early postoperative mobilization.

In the implementation of nursing actions seem confident participants, some participants were responsive to the patient's complaints, but there are also participants who are less responsive to patient complaints. Participants also seemed rarely discuss the results of laboratory and other findings in the medical team.

\section{Effective Communication}

Based on the observation, the participants have not applied effective communication with patients. Participants rarely introduce themselves to patients and families. Participants rarely ask patients about anesthesia options that patients desired and rarely explain it (the effects of anesthesia and others). Participants rarely listened attentively to the patient. Not all patient questions answered by participants, participants sometime forgot to answer that has been promised by the participants to the patient when the patient asks if participants do not give a definite answer.

\section{Support}

Observations indicate that the participants provide comfort to the patient, such as when entering the recovery room (recovery room/RR) were rather cold, participants gave a blanket on the patient. Participants install a safety bed to ensure the safety of patients. Participants also encouraged the patient so that the operation can be run properly. However, not all participants showed the same thing. 
Not all participants allowing the patients to express positive and negative feelings towards nurses. Participants also seemed less motivated patients to be involved in the care of her as rarely seen motivate patients to perform early postoperative mobilization, but in the room seemed to care the patient's family be allowed to accompany the patient during surgery unless there is a waiting room for patients' families.

\section{Respect}

The results obtained participant observation respect for providing care to patients, it can be seen from the action participants always appreciate patients, always maintain the confidentiality of patient information, always act with courtesy and care, allowing patients to be involved in providing care to patients.

\section{Being with}

The results showed that participants rarely observations apply to being with the patient, as participants rarely sit next to the patient to communicate while maintaining eye contact, putting a hand on the shoulder of the patient to convince patients that they (nurses) are always present to the patient and nurse care to patients. Regular participants took the time to explain to patients about actions to be taken of participants and answer any questions the patient, but participants rarely make sure that the patient fully understands what has been delivered. Participants also rarely allow the patient to express his feelings without feeling pressured. Participants also rarely tell the patient "is there anything else that I can help you?" Participants also seemed rarely do assessments regularly and observe the action he had performed without the patient or family to call the nurse (patient's family always call participants for example during intravenous fluids discharged). Lacking in depth assessment conducted so that less identified needs of the patient.

\section{Doing for}

The results showed that the participant doing quite well in this aspect for. during intra- operation, participants always monitor the patient's condition, in the OK/RR precautions against the state of the physical environment that could harm the patient has been made by participants such as installing security beds, the rooms were clean physical environment and the floor is not slippery, in a deft move patients from bed to trolley or vice versa, in room RR also always take an assessment of the respiratory status of the patient (airway, breathing, and circulation). However surgical ward seem less help patients in a variety of activities, in which patients have limitations, such as during the post- surgery in which patients have limitations in performing ADL movement to meet the requirements for postoperative pain, rarely seen as participants help patients overcome postoperative nausea and vomiting felt by the patient, monitoring or evaluation of the current state of the patient are less common, especially in the post operative surgical care, preventive measures against postoperative infection is less common, more participants only execute the management of administration of medication in accordance with physicians advice. Participants also seen rarely discussed by doctors associated abnormal laboratory results were found in patients, including discharge planning for patients still less do the participants.

\section{DISCUSSION}

\section{Utilizing knowledge and skills}

Nursing as Caring focuses on the knowledge needed to understand the individual as a human being. Knowing is an attempt to understand the events in the lives of others, avoid assumptions, the focus of caring for others, look for clues, examine carefully and incorporating the nurse - patient in the process of knowing (Swanson, 1991 in Hood \& Ledd, 2006, Swanson, 1999 in,Tomey \& Alligod, 2006). Supphanock, et al (2010) that one of the aspects of the nurse caring was using his professional knowledge and skill while providing relief to the patient.

The results of this study indicate that the use of the knowledge and skills demonstrated by the participants are still lacking in providing 
perioperative nursing care to patients primarily in providing health education (explanation of pre and post surgery) are also seen rarely discussed with patients (in an effort to overcome anxiety or fear of the patient during the surgery).

These results are in line with research Krupic, F. et al. (2012) that preoperative education provided to patients is not robust. Also research Ardiana (2010) that $46 \%$ of nurses are still considered less caring by patients.

The use of the knowledge and professional skills of nurses in providing nursing care is the basis or foundation of professional nursing as a form of caring behavior of nurses. The nurse caring behavior of the most important in the surgical treatment is know what to do, overcoming anxiety preoperative, postoperative pain management, explanation the anesthetic and prevent postoperative complications. One of the nurse's role as a leader in the preoperative change agent acts as educator and is responsible for the education and assessment of surgical patients. If the role is done, it can contribute in reducing changes to the specified operating schedule (delay or delay in operation). Also the risk of infection and postoperative intra- operation can be derived.

During the study period, the researchers observed that participants were not performing its role as a leader of change agent. This is due to the high workload of nurses, time constraints and the number of patients who have surgery by the nurses there, where the number of nurses on duty in each shift in the surgical ward and in the operating room each just only five people. In addition, the education of nurses which is still dominated Diploma of Nursing, Bachelor of nursing and ners still lacking.

It is undeniable that create of caring behavior not only genetic but also contribute to the level of education in the formation of the caring behavior. Caring is not something abstract, but must be expressed with full knowledge. Repair or recovery of patients depends on the patient's physical and psychological factors. Both these factors are also dependent on the knowledge of the patient, the patient's ability and confidence to recover. One way to improve the knowledge of the patient is the provision of information in this preoperative given to the patient's nurse during the preoperative period (health education).

Various studies have shown that preoperative information can improve better care and speed recovery after surgery (Aasa Agneta, Hovback, and Bertero, 2013). Through perioperative education can improve patient understanding and provide more information about the surgery patients can reduce anxiety and fear of patients during surgery.

Researchers assume that the knowledge/ understanding of the patient can be increased through the provision of information related to the patient's health and in the delivery of health education preoperatively, preoperative nurse should plan individual teaching and learning needs to determine the needs of the patient. As it is known that perioperative nurses have limited time so nurses need to check directly with the patient about what will be learned related to the operation and post- operation. This can help nurses with limited time to provide information to patients who also have limitation in receiving information (Kruzik, 2009).

In the implementation of nursing care is essential to admit the existence of the patient, making the patient to participate and take responsibility for his health. With a good knowledge of the patient who owned the participation and responsibility of the patient to the health of patients may be increased so that independence can be achieved.

\section{Effective Communication}

Effective communication is one form of a trusting relationship. Stuart and Laria (2005) states that communication is an important thing that should be applied in nursing practice because communication is a tool to build a therapeutic relationship. In addition, the communication becomes the media to influence the behavior of others, so that without communication, the therapeutic nurse - patient relationship may not be established. 
The results of this study indicate that the participants have not implemented effective communication with patients, where participants rarely introduce themselves to the patient and family, rarely giving an explanation, the patient rarely listened to attentively.

Lachman, VD (2012) that in order to build a relationship of trust, caring relationships with patients, nurses must be able to listen to his/hers conscience and listen to others (patients and families). Rego, Godinho, \& McQueen (2008), that nurses are able to understand her feelings, so it is able to act and communicate in an appropriate manner and with full of awareness. The result of this study seem participant observation rarely listen to the complaints of patients and families with full attention.

Communication is very important during the perioperative process due to patient depending on the health care professional. Selimen D and Andsoy, I (2011), that real success of the perioperative nurse is communication and listen. Researchers assume that through good communication, nurse more easily analyze the patient and family members. Communication is very important for perioperative nurses to obtain the information needed to understand and evaluate the patient and family quality of health service. Nurses in any action should begin with therapeutic communication to patients and families so that nurses can be trained to communicate.

\section{Support}

Swanson (1991, in Hood \& Leddy, 2006) support including efforts enabled (enabling) that facilitates the patient to pass through a period of transition or unusual events by focusing on the situation, provide information or explanation, support, validate the patient's feelings, offer options (alternative) action and provide feedback. Supphanock, et al (2010) that support is part of the nurse caring behavior. In this case, the support associated with the healing process of the patient, reduce patient suffering and emotional stress. Support helps nurses understand the needs of physical, psychological, social and spirituals patient.
This study showed that participants provide enough support to the patients as providing actions that ensure comfort and safety for patients, to motivate patients undergoing surgery, but less motivating the patient to improve the patient's ability to care for herself. Not all participants gave praise to the patient when the patient failed to show the progress of his health.

Selimen D and Andsoy I. (2011), that support is important in the perioperative care of surgical patients and a need and their families. Sukesi Research (2011), that dimension was less for nurses in the show caring behavior is to meet the needs of the bio-psycho-sociocultural and spiritual patient.

Perioperative nurses contribute in providing holistic care ranging from the early stages of preparation operations until the end of surgery (postoperative). Selimen D and Andsoy I. (2011) state that the perioperative period cause physical and psychological stressors for patients and their families. Perioperative nurses are responsible for providing a therapeutic environment for surgical patients and their families. Research Norred, CL (2007) that by reducing patient anxiety can facilitate the healing process of patients, increase customer satisfaction and improve the effectiveness of the surgical procedure. Providing holistic care, perioperative nurses can help patients coping easier to cope with the trauma of surgery, reduce pain, reduce the use of analgesics, and avoid postoperative complications.

This form of support is also evidenced by the receipt of expressions of feelings, both positive and negative patients. In this study, participants seem less provide an opportunity for patients to express their feelings, both positive and negative. This is due to the time constraints of participants, the lack of response personnel and considerable number of patients so that participants are less motivated patients to express their feelings.

Acceptance of nurses on the expression of positive and negative feelings of the patient can make the patient wishes to recover. Nurachmah (2001) stated that the nurses gave time to listen to all complaints and feelings 
of the patient. Stuart \& Laraia (2005), that listening to the patient's expression of feelings about his desire to heal, motivate patients to express their feelings, both positive and negative as part of the strength of the nurse and the nurse explained the self-understanding of the acceptance of the patient's condition. This is also includes in the psychological aspects of holistic care.

Researchers analyzed that the support is part of the nurse caring behavior. In providing professional care, we can not only see the physical aspect but the "see" of patients as a whole bio - psycho - socio - spiritual then the nurse can meet the needs of patients, especially the physical and psychological needs of the patient so that the patient can feel benefits. Thus, to increase patient satisfaction and quality of nursing care also increased. The success of surgery for patients not only means the patient can go home faster, but also regain their physical, mental and spiritual as a whole.

\section{Respect}

Swanson (1991, in Hood \& Ledd, 2006) respect is part of maintaining trust, which maintains patient confidence by trusting patient capacity, maintaining a hopeful behavior, offering realistic expectations, helping to find meaning and is always ready to assist the patient in all situation. Respect is one of the humanistic and altruistic values. Watson (2005) said that the values of humanistic and altruistic learned early in life, but it is heavily influenced by education. Nurse caring behavior which reflects the formation of a humanistic value system is to appreciate or respect for the patient as an individual (human).

The results of this study indicate that the participants enough respect for patients, as indicated by the behavior of participants who appreciate the patient, act polite and careful in every nursing action, always maintaining the confidentiality of patient information and involve the patient's family to assist patients in performing activities of daily living.

Supphanock, et al (2010) said that occurs when nurses receive respect and acknowledge the presence of the patient as an individual. Respect used in a context that focuses on maintaining the patient's dignity and integrity. Caring as a process which nurses to responsive to each patient as a unique individual. Patients need a caring nurse and the patient's understanding of the expectations of the professional nurse. Martinsen (1989, Tomey \& Alligood in 2006) said that this form of care is not just a basic value of nursing, but also a basic prerequisite for life. Care includes three things: relationships, practices and moral simultaneously. Respect is part of the three issues.

Researchers assume that the behavior of the nurses who showed respect (respect or respect for the patient as an individual, working as a team in implementing nursing care) reflects the formation of a humanistic and altruistic value system. However, when a nurse decided to be a "nurse" in his life then it should have a commitment to care for all patients in accordance with established nursing ethics code: "The nurse respect the worth, dignity and rights of all human beings irrespective of the nature of the health problems".

\section{Being with}

Being with or presence that brings emotion when with others. This includes the presence of nurses to patients themselves, communicate readiness (willing) to help and share their feelings without burdening patients (Swanson (1991, in Hood \& Leddy, 2006). Being with the case when the time spent with the patient's nurse to meet the needs of patients, without patients feel overwhelmed, show interest and concern for the patient's condition, to respond quickly to the needs of patients, visit patients on a regular and ongoing basis (Supphanock, et al, 2010).

Based on observations of this study indicate that participants are less being with which participants rarely spend time with the patient, with the patient sitting, showed less interest in attention to the problems and suffering of the patient, not fast enough to respond to the needs of patients, less visited patients regularly and continuously.

This study is also in line with several other studies related to the nurses caring 
behavior was one of Sukesi (2011) that nurses are less controlling and condition of the patient's complaints every day, less listening to the patient's expression of feelings. Ardiana Research (2010) that the majority of nurses do not help or guide the patient in meeting basic needs according to ability or inability of the patient.

Researchers analyzed participants showed that such behavior because of high workload in which participants also perform non- nursing jobs were pretty much as consul doctor, taking care of the patient administration, but the nurse should be able to provide guidance and assist patients in meeting the basic needs of the patient with the patient's independence goals. Listening to the patient's complaints, regularly visit patients in order to know what is required of patients and the development of the patient's condition. To implement this will require a sense of self so that the nurse is a nurse is able to understand the other person (the patient).

Boykin A and Schoenhofer S. (2013) said that in applying the necessary understanding of being with yourself and others. Researchers analyzed that with being associated with emotional intelligence being a nurse because the nurse brings with emotion when with the patient. Self-consciousness or self-awareness is a combination of skills and abilities such as self-awareness, self-control, empathy and sensitivity to the feelings of others (Ivancevich, Konopaske and Matterson, 2005).

Rego, Godinho, and McQueen (2008) that nurses are able to understand her feelings, it would be able to act and communicate in an appropriate manner and with full awareness. Nurses must be able to assess her emotions, emotional self- understanding and acceptance that will either facilitate nurses to understand the differences and uniqueness of the patient as well as more sensitive to the needs of others. Nurachmah (2001) that nurses are sensitive to the feelings and able to be fair to others.

Self awareness can be enhanced by the nurse listening heart, listen and learn from others and express what is felt. Eye contact helps to understand and appreciate the person as a form of caring behavior. In addition, to understand the patient's important to listen and respond to patients' needs, as important as spending time with the patient (Allvin, 2008).

Health care professionals need to be aware that patients experience varies so it is necessary to listen to the complaints of the patients (Eld et al., 2006). Being an active listener is important in patient care, including the implementation of perioperative nursing care. Selimen D and Andsoy I. (2011) that is also required in the perioperative care nurse who listens to the patient, asking questions as appropriate, to give a sincere response to the question and ensure that patients understand what they have delivered. In the process, the nurse should ensure that the patient does feel comfortable. Thus the patient can decrease anxiety and help patients to return to normal as possible because this is one of the goals of perioperative care.

\section{Doing for}

Doing for or conduct that is taking action for others or the patient 's independence if possible, include the act of anticipation, comfort, displays competence and expertise, to protect the dignity of the patient and the patient (Swanson, 1991 in Hood \& Leddy, 2006). Doing for nurse action which is intended to honor the patient by providing physical and mental care including medical management (Supphanock, et al, 2010). Leininger (2001, in Tomey and Alligood, 2006) that doing for as one dimension of caring is an action or activity that is directed to provide care (care).

This study showed that the participants quite well in the show for which participants have been doing quite well in providing intraoperative nursing care, but during presurgery and post- surgery was less common.

Good care requires competence of individuals who care (Vanlaere, L \& Gastmans, C 2011). Zhang et al (2000, in Rafii, Hajinezhad, and Haghani, 2009) that contribute to the effectiveness of nurse competence of nurses and patient satisfaction performance. Lachman (2012) also said that the nurse should be responsible for updating their competencies continuously. Nurse competence and caring are 
two things that are essential to safety (patient safety) and the quality of nursing care.

Research Zamanzadeh, et al (2010) showed that aspects of competence in the implementation of nursing care that is needed is to assess the patient's state of the patient, making it easier to determine what is needed for the patient and easier for patients receiving nursing care. During the preoperative period, nurses perform a complete physical assessment of the patient, obtain a complete medical history of the patient, asses for infection, review of results of diagnostic studies and laboratory result. It also did health education (Boykin A. and Schoenhofer S, 2013).

However, in this study, it has been mentioned earlier that preoperative treatment is still lacking performed by participants, where participants rarely do a complete assessment of the patient which can be justified by the charging status of the patient's format are still many unfilled related patient assessment, participants also rarely seen discussing diagnostic workup and laboratories in the team caring for the patient (medical and paramedical). Health education mostly to alleviate preoperative anxiety, whereas health education associated postoperative pain and mobilization is rarely done. Evaluation of patients' knowledge about the material has been given health education rarely done.

On postoperative, monitoring the patient's condition, including the management of pulmonary status, hemodynamics, bleeding, neurologic, urinary system, gastrointestinal, and pain management is done quite well by the participants during the intraoperative and postoperative in the Recovery Room (RR), but such measures are less common while in the room surgical treatment (postoperative phase) mainly on the management of postoperative pain and early mobilization actions.

This is caused by the number of nurses is lacking, especially in the surgical treatment, the existing equipment in the RR is more sophisticated than those in the treatment room so much easier to monitor, workload increased in the treatment room for patients facing not only the postoperative but also the patient preoperatively.

Researchers assume that if the role of preoperative nurse when accurately executed, it can contribute in reducing the risk of intraoperative and postoperative complications. This is also evidenced Martin \& Turkelson study (2006) showed that providing health education to the patient before surgery may help in the healing process of patients, increase patient satisfaction and decrease complications.

Researchers also assume that it is related to the competence of nurses. Competence as a condition for effective interaction and health care professionals through competency of nurses can provide holistic nursing care to patient. Caring in professional nursing occurs in every nurse - patient interaction.

To be caring, nurses need the capacity and ability to care. Nursing as a science requires the use of knowledge in every aspect. Watson (2003, in Vance, 2012) that caring may occur without curing (treatment), but curing can't occur without caring. Caring as an interpersonal characteristic that are not genetically inherited, but learned through a cultural education as a profession. For that we need an increase in nurse education and realize the responsibility for the performance of self nurses can be improved through performance appraisal objective and accurate, and the reinvigoration of the rights and responsibilities of nurses.

\section{CONCLUSIONS}

The participants were quite good in showing the caring behavior of nurses for providing perioperative nursing care. Caring as tangible evidence of nursing actions based on the desire to understand, help, and reduce the suffering of patients with the best action for the health of the patient based on good values to improve patient satisfaction and the patient's independence. Improved aspects of knowledge, skills, competence and awareness of nurses needed in improving nurse caring behavior. 


\section{RECOMMENDATIONS}

Educational institutions to further enhance the knowledge of students about caring behavior. Curriculum development related to caring behavior needs to be improved further and applied in each nursing education curriculum resources. As a reference for nurses to better understand nurses caring behavior so as to apply it in implementing the care and professionalism in nursing can improve. Nurses are also expected to constantly improve their competence through increased education and training.

\section{REFERENCES}

Aasa Agneta, Hovback, and Bertero, 2013. The importance of Preoperative information for patient participation in colorectal surgery care. Journal of Clinical Nursing, (22), pp. 11-12.

Allvin. 2008. Experiences of the postoperative recovery process: an interview study. Open Nursing Journal 2, 1-7.

Ardiana. 2010. Hubungan Kecerdasan Emosional Perawat dengan Perilaku Caring Perawat Pelaksana Menurut Persepsi Pasien di Ruang Rawat Inap RSU Dr. H. Koesnadi Bondowoso. Tesis. Unpublished. Fakultas Ilmu Keperawatan. Universitas Indonesia.

Boykin A and Schoenhofer S. 2013. Nursing As Caring: A Model for Transforming Practice. Jones and Bartlett Publisher. Boston.

Dossey BM. 2007. Integral and Holistic Nursing. AORN Journal. 27(2).

Eld et al. 2006. Conditions for patient participation and non-participation in helath care. Nursing ethics. 13(5). 503-514

Hill, T. 2013. Caring and Technology. Journal of Nursing Informatics. 17(3).

Hood. L.J., \& Leddy, S.K. 2006. Leddy \& Pepper's Conceptual Bases of Pr0fesional Nursing. (6th Edition). Philadelphia: Lippincott Williams \& Wilkins.

Ivancevich, J.M., Kanopaske, R. \& Matterson, M.T. 2005. Organizational Behavior and Management. North America: Mc. Graw-Hill
Kostak MA. 2007. Spiritual Dimension of Nursing Care. AORN Journal. 2(6): 105-115

Krupic, F. et al., 2012. Preoperative Information Provided To Patient Before Surgery. AORN Journal. 66(6).

Kruzik. 2009. Benefit of Preperative Education for Adulth Elective Surgery Patients. AORN Jurnal. 90(3).

Lachman, V.D. 2012. Applying the ethics of care to Your Nursing Practice. Medsrg Nursing Journal. 21(2)

Martin \& Turkelson. 2006. Nursing Care of The Patient Undergoing Coronary Artery Bypass Grafting. Journal of Cardiovascular Nursing 21(2): 109-117

Merkouris A, Andreadou A, Athini E, Hatzimbalasi M, Rovithis $M$, Papastavrou E,. 2013. Assessment of Patient Satisfaction in Public Hospitals in Cyprus: A descriptive study. Health Science Journal. 7(1): 28-40

Mira JJ, Tomas O, Virtudes-Perez M, Nebot C, Rodriguez-Martin J,. 2009. Predictors of Patient Satisfaction in Surgery. Surgery Journal. 145(5): 536-541.

Norred, CL. 2007. Minimizing Preoperative Anxiety With Alternative Caing-Helaing Therapies. AORN Journal. 72(5).

Nurachmah, E. 2001. Asuhan Keperawatan Bermutu di Rumah Sakit. Perhimpunan Rumah Sakit Seluruh Indonesia (PERSI). Juli 20. 2014. http://www. polpersi.co.id/?show=detailnew $\&$ kode $=786 \&$ tbb $=$ artikel

Nursalam. 2014. Caring Sebagai Dasar Peningkatan Mutu Pelayanan Keperawatan dan Keselamatan Pasien. Orasi Ilmiah Pengukuhan Jabatan Guru Besar Fakultas Keperawatan Universitas Airlangga. Surabaya.

Rafii, Hajinezhad, and Haghani. 2009. Nurse Caring in Iran and Its Relationship with Patient Satisfaction. Australian Journal of Advance Nursing. 26(2)

Rego, Amenio, Godinho, Lucinda, \& Mc.Queen Anne. 2008. Emotional Intelligence and Caring Bahavior in Nursing. Juli 21, 2014. http://www.ibacnet.org/bai.2007/ proceeding/papers/2007bai7810.doc

Samina M, Qadri GJ, Tabish SA, Samiya M, Riyaz R. 2008. Patient's Perception of Nursing Care at a Large Teaching 
Nurses' Caring Behaviors in the Implementation of Perioperative Nursing Care (Heltty)

Hospitasl in India. International Journal of Health Siences. 2(2): 92-100.

Selimen D and Andsoy I. 2011. The Importance of a Holistic Approach During The Perioperative Period. AORN Jurnal. 93 (4): $482-490$

Stuart, G.W. \& Laraia,M.T. 2005. Principles and Practice of psychiatric Nursing. (8th Edition). USA: St. Mosby Inc

Sukesi N. 2011. Hubungan Caring dengan Pemenuhan Kebutuhan Rasa Aman Pasien di RSI Sultan Agung Semarang. Tesis. Unpublished. Fakultas Ilmu Keperawatan. Universitas Indonesia.

Suphaphon Udomluck, Ouyporn Tonmukayakul, Sujitra Tiansawad, Wichit Srisuphan. 2010. Development of Thai Nurses' Caring Behavior Scale Pacific Rim Int J Nurs Re: 14(1) 32-4

Tomey, A.N. \& Alligood,M.R. 2006. Nursing Theorists and Their Work. USA: Mosby Elsevier
Vance, T. 2012. Caring and the professional practice of nursing. RN Journal. Available at http://www.rnjournal.com/ journal_of_nursing/caring.htm

Vanlaere,L \& Gastmans, C, 2011. A Personalitistic approach to care ethics, Nursing Ethics Journal, 18, 161-173

Watson, Jean. 2012. Nursing Theories. Diambil dari Http://currentnursing.com/nursing theory/watson.html tanggal 10 April 2014

Werner JS, Wendler MC, McCormick J, Paulus-Smith S, Jackson C, Nie J. 2012. Human Response outcomes influenced by nursing care. Int J Hum Caring. 6(3): 15-23

Zamanzadeh, et al. 2010. Oncology patients' and professional nurses' perceptions of important nurse caring behaviors. BMC Nursing. 9(10) 